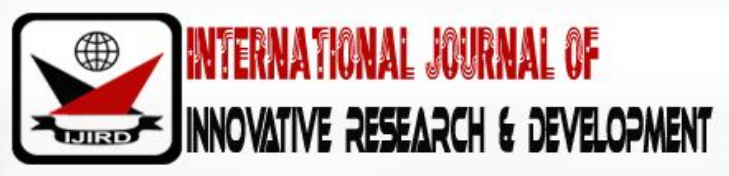

ISSN 2278 - 0211 (Online)

\section{Factors That Influences the Adoption of E-Commerce in the Ghanaian Banking Industry}

\author{
Carlo K.M.H. Adadevoh \\ Ph. D. Student, Accra Institute of Technology, Open University of Malaysia, Malaysia
}

\begin{abstract}
:
The liberalisation of the banking and telecommunication sectors in Ghana has resulted in the increase in the number of banks and internet service providers in the country. Adopting technological developments over time, banks in Ghana have gradually shifted from dependence on physical presence of clients for financial transactions to branchless and e-banking. In addition to improvements in services and products, banks also operate in an environment of e-commerce in which some business transactions are performed using telecommunication channels. Various factors have been reported to influence the adoption of e-commerce in Ghana. This study considers factors which influence e-commerce adoption in the banking industry in Ghana.
\end{abstract}

Keywords: E-commerce, e-banking, e-readiness

\section{Introduction}

Calls for innovation in businesses, including financial services, have been made alongside improvements in technology ${ }^{1}$. E-commerce is the conduct of commercial transactions using telecommunications networks2-5. These transactions include information exchanges, marketing, buying, selling, and maintaining business relationships ${ }^{2}$, 5 . Due to differences in existing technologies, the conduct of e-commerce varies across countries. There is a shift from dependence on electronic data interchange (EDI) to internet-based transactions, and this has further affected the meaning of e-commerce across different countries $^{6,7}$. The forms that e-commerce takes include business-to-business (B2B), business to client (B2C), and business to government (B2G) ${ }^{8}$.

An important factor in the conduct of most economic activities including e-commerce is a channel for financial flow, mostly provided by banks. Banks are legally mandated institutions that managefunds ${ }^{9}$. Globally; the banking sector has witnessed modifications over the years ${ }^{1}$. The evolution of banking services has been in response to client demands and technological improvements. In Ghana, the decision by the Bank of Ghana to liberalise the financial sector is credited for the increase in the number of banks from 1 in 1874 to 34 as at December 201610,11. Of significant note is the provision of traditional and new banking services to clients using an electronic channel, and known as electronic-banking ${ }^{12}$. This has resulted in a shift from traditional banking practices and services to include internet banking, mobile banking and the use of ATMs ${ }^{1}$. With e-banking facilitating branchless banking, it has reduced the need for the physical presence of clients as previously requiredfor bankingtransactions ${ }^{13}$.

E-banking services have grown from information-pushsystems,through information-downloadsystems,to fulltransactionsystemswhich allow clients to initiate transactions to which their bank provides the services requested ${ }^{14}$.Banks nowprovide some of its clients with tailored e-banking services;in response to the recognition of e-banking as a better tool for banks to gain an edge in its competitive market. In Ghana, e-banking was introduced in the 1990s, and services include checking account balances, funds transfer, payment of bills, and requesting for account statements ${ }^{14}$.

In Ghana, the introduction of the National ICT for Accelerated Development policy by government in 2003 is seen as a deliberate effort to facilitate ICT based development including e-commerce ${ }^{3}$. However, the technological capabilities of banks in influencing e-commerce is affected by the broader technological conditions of the country in which the bank operates ${ }^{3}$. This is in addition to individual differences which make banks differ in their facilitation of e-commerce 3 . The importance of ecommerce includes a reduction in transaction costs, creation of ICT business employment opportunities, and improvement in efficiency in commercial transactions ${ }^{1,15-17}$.

Different factors have been indicated as influencing e-commerce in the banking industry. Some includepre-adoption knowledge, internet accessibility, security of the online service, and a supportive environment as influencing ecommerce ${ }^{14}$.Others also report social networks, managerial capabilities and government commitment as influencing the adoption and use of e-commerce 3 . For this study, an assessment of factors which influences e-commerce in banks will be based 
on the Perceived Organizational E-Readiness (POER) model, in which managerial, organizational and technological factors of banks would be considered $3,15,18$.

\section{Materials and Methods}

This study was conducted as a survey. The study population included all the 34 formally registered banks in Ghana. Using a confidence level of $90 \%$ and a $10 \%$ margin of error, a sample of 29 banks were selected using simple random technique. Targeted respondents were individuals with knowledge about the e-commerce and e-banking services of the bank. For primary data, a questionnaire was administered to the respondents and responses ranked using a Likert scale. Secondary data were obtained from existing literature to allow comparisons to be made from results obtained from the study. Results were presented as frequency tables.

The reliability test of all of the variables is presented in the Table 1. As can be observed from Table 1, all the independent variables passed the reliability test since the reliability values were all above 0.700 . This suggests that the independent variables are reliable and the results obtained can be generalized.

\begin{tabular}{|c|c|c|}
\hline Variables & Items & Cronbach's Alpha \\
\hline Technology readiness (TR) & 9 & 0.901 \\
\hline Organizational Commitment (OC) & 3 & 0.877 \\
\hline Perceived Benefit (PB) & 4 & 0.895 \\
\hline Competition Intensity (CI) & 4 & 0.763 \\
\hline E-commerce Adoption (EC) & 5 & 0.970 \\
\hline
\end{tabular}

Table 1: Reliability Analysis

\section{Results}

\subsection{Demographic Characteristics of Respondents}

Out of the eight-seven (87) respondents selected from twenty-nine (29) banks, only seventy-eight (78) questionnaires were retrieved for the analysis representing a response rate of $89.7 \%$. Table 2 presented the demographic characteristics of respondents. Most of the participants were operations manager (representing 30.8\%). About 19.2\% were branch managers, while others were Assistant Vice President, OG-2, OG-3, IT officers and clerks. Also, it was observed that most of the banks (representing 50\%) have operated for over 10 years, while remaining respondents indicated their banks have operated for a period ranging between 4 to 10 years.

Again, 35.9\% of the respondents indicated that their banks have between 15 to 20 branches. About $32 \%$ of the respondents noted that their banks have more than 20 branches. Finally, most of the respondents (representing 39.7\%) are bachelor's degree holders, 30.8\% are post-graduate degree, $15.4 \%$ have HND certificate and 14.1\% are professional certificate holders.Majority of the respondents indicated that some of the e-banking product offered by their banks are ATM/ Debit card services, transfer funds to other customers in different domestic banks, transfer funds between customers' accounts at the bank, email notifications services, request cheque books and initiating loan repayments.

\begin{tabular}{|c|c|c|}
\hline Variable & Frequency & Percent (\%) \\
\hline Position & & \\
\hline Assistant Vice President & 5 & 6.4 \\
\hline Branch Manager & 15 & 19.2 \\
\hline Operation Manager & 24 & 30.8 \\
\hline OG-2 & 6 & 7.7 \\
\hline OG-3 & 9 & 11.5 \\
\hline IT Officer & 10 & 12.8 \\
\hline Clerk & 9 & 11.5 \\
\hline Years in operations & 28 & 35.9 \\
\hline 4-6 years & 11 & 14.1 \\
\hline 7-10 years & 39 & 50.0 \\
\hline Above 10 years & & 12.8 \\
\hline Number of Branches & 10 & 19.2 \\
\hline 6-10 & 15 & 35.9 \\
\hline 11-15 & 28 & 32.1 \\
\hline 15-20 & 25 & \\
\hline Above 20 & & \\
\hline
\end{tabular}




\begin{tabular}{|c|c|c|}
\hline Variable & Frequency & Percent (\%) \\
\hline Education & & \\
\hline HND & 12 & 15.4 \\
\hline Bachelor's Degree & 31 & 39.7 \\
\hline Post-Graduate Degree & 24 & 30.8 \\
\hline Professional certificate & 11 & 14.1 \\
\hline
\end{tabular}

Table 2: Demographic Characteristics of Respondents

Figure 1 presented the responses provided by respondents on the issue of customers patronizing e-banking services. As shown in Figure 1, most of the respondents (representing 79.5\%) indicated that customers patronize their e-banking services while $19.2 \%$ did not know if customers patronize e-banking services.

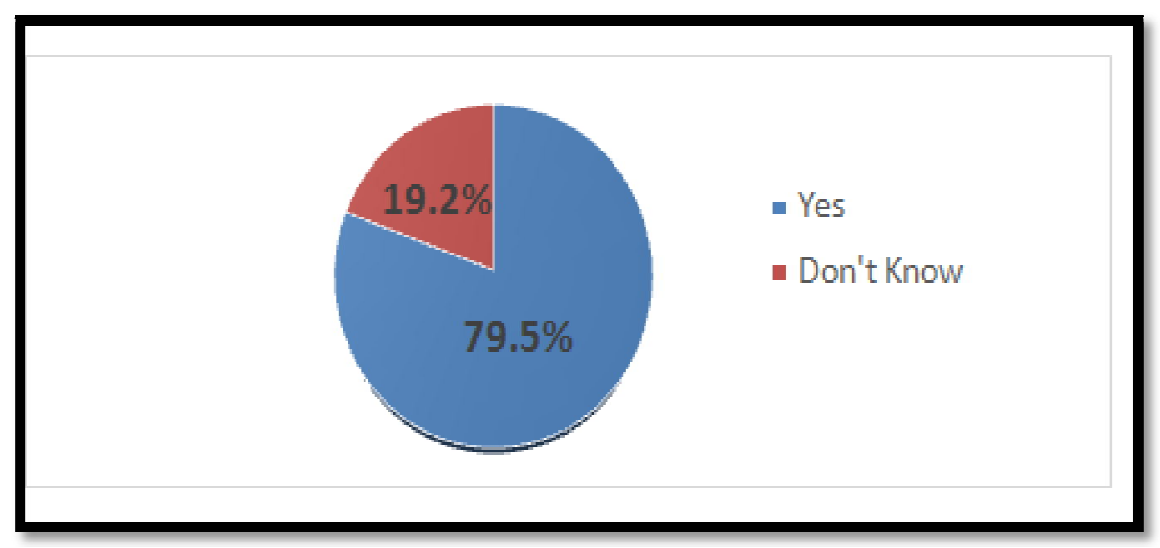

Figure 1: Are Customers Patronizing E-Banking Services

\subsection{Multiple Regression Analysis Results}

Before conducting the multiple regression analysis, a test for normality, linearity, multicollinearity, homoscedasticity and checking outliers were performed. Based on the test conducted it was shown that the data used satisfied all the requirement of multiple regression analysis. Table 3 presents the Analysis of Variance results. As can be observed from Table 2 , the adjusted R-square obtained was 0.780 . This implies that $78 \%$ of the variations in e-commerce adoption can be explained by the independent variables (technology readiness, organizational commitment, perceived benefits and competition intensity).Also, overall regression model obtained a F-statistic of 68.455 with a p-value of 0.000 . This implies that collectively all the independent variables included in the model have significant effect on e-commerce adoption.

Table 4, represents estimated model. As can be observed from Table 3, all the independent variables have a positive effect on e-commerce adoption. Three out of the four independent variables had a p-value which was below the significance value of 0.05 and they are technology readiness, organizational commitment and perceived benefit. Thus, technology readiness, organizational commitment and perceived benefit have a significant effect on e-commerce adoption. It can be noticed that competition intensity had a p-value greater than 0.005 suggesting that it does not influence ecommerce adoption.

\begin{tabular}{|l|l|l|l|l|l|l|}
\hline Model & $\begin{array}{l}\text { Sum om } \\
\text { Squares }\end{array}$ & df & Mean Square & F & Sig. & $\begin{array}{l}\text { Adjusted R } \\
\text { squared }\end{array}$ \\
\hline Regression & 24.220 & 4 & 6.055 & 68.455 & .000 & 0.780 \\
\hline Residual & 6.368 & 72 & .088 & & & \\
\hline Total & 30.588 & 76 & & & & \\
\hline
\end{tabular}

Table 3: Anova Results

a. Dependent Variable: E-Commerce Adoption

b. Predictors: (Constant), Ci, Tr, Oc, Pb 


\begin{tabular}{|c|c|c|c|c|c|}
\hline \multirow{2}{*}{ Model } & \multicolumn{2}{|c|}{ Unstandardized Coefficients } & \multirow{2}{*}{$\begin{array}{c}\text { Standardized } \\
\text { Coefficients }\end{array}$} & \multirow{2}{*}{ t } & \\
\cline { 2 - 4 } & B & Std. Error & Beta & & \\
\hline (Constant) & -2.116 & .462 & & -4.584 & .000 \\
\hline TR & .640 & .185 & .542 & 5.464 & .000 \\
\hline OC & .704 & .113 & .544 & 6.253 & .000 \\
\hline PB & .734 & .143 & .537 & 5.120 & .000 \\
\hline CI & .161 & .145 & .111 & 1.117 & .268 \\
\hline
\end{tabular}

Table 4: Estimated Model

Table 4 presents the relative importance index (RII) result on barriers to ecommerce. As can be noticed from Table 4, all the sixteen (16) challenges to ecommerce adoption obtained a RII score above 0.5. This suggests that respondents identified all the sixteen (16) factors as challenges to ecommerce adoption. However, the top five challenges to ecommerce adoption are as follows: cost factors $(\mathrm{RII}=0.930)$, reduction in customer - bank relationship (RII=0.926), internet support systems (RII=0.921), reduction in customers trust in bank $(\mathrm{RII}=0.894)$ and limited skills base of staff $(\mathrm{RII}=0.894)$.

\begin{tabular}{|c|c|c|}
\hline Challenges & RII & Rank \\
\hline Lack of applicability to business & 0.782 & 15 \\
\hline Preference for traditional transacting methods (paper-based transactions) & 0.802 & 13 \\
\hline Enabling factors (ICT skills, qualified personnel, network infrastructure) & 0.785 & 16 \\
\hline Cost factors (of ICT, network, software, e.g.) & 0.930 & 1 \\
\hline Security and trust factors & 0.881 & 6 \\
\hline ICT competencies in business firm & 0.881 & 6 \\
\hline Internet support systems & 0.921 & 3 \\
\hline Lack of familiarity & 0.862 & 10 \\
\hline Cultural reluctance & 0.869 & 9 \\
\hline Perceived customer readiness & 0.827 & 12 \\
\hline Lack of executive support & 0.808 & 13 \\
\hline Leluctance of companies to network with other companies & 0.846 & 11 \\
\hline Lack of Technical and managerial skills & 0.881 & 6 \\
\hline Limited skills base of staff & 0.894 & 4 \\
\hline Reduction in customers trust in bank & 0.894 & 4 \\
\hline Reduction in customer - bank relationship & 0.926 & 2 \\
\hline
\end{tabular}

Table 5: Barriers to E-Commerce

\section{Discussion}

This study examined the factors that influence ecommerce adoption in the banking industry. Technology readiness had a positive effect on ecommerce adoption. This implies that banks with good telecommunication infrastructure and highly specialized and knowledgeable IT employees are likely to adopt ecommerce in their operations. This finding is consistent with previous studies such asLin \& Lin (2008); Morrison \& King (2002) and Wang \& Cheung (2004).

Their studies revealed that companies with sufficient level of information technology resources have increased their chances to successfully adopt e-commerce. Also, the study showed that organizational commitment has a positive effect on ecommerce adoption. This result suggests that banks with consistent work practices and existing beliefs have higher chance of adopting ecommerce in their operations. This finding is consistent with the findings of Al-Qirim (2005), Gibbs \&Kraemer (2004). Perceived benefit has a positive effect on ecommerce adoption. This means that banks will adopt ecommerce only if it has more advantages than previously used technology. This finding is consistent with the findings of Lin \& Lin (2008) who found that higher the level of expected advantages of e-commerce adoption will promote the use of e-commerce by firms.

\section{Conclusion}

Based on the findings from the study, it can be observed that the adoption of e-commerce by banks in Ghanais influenced by factors such as technology readiness, perceived benefit and organizational commitment. The study also established that the main challenge to ecommerce adoption among banks is the cost factor of ICT, network and software. 
6. References

i. Domeher, D., Frimpong, J. \& Appiah, T., 2014. Adoption of financial innovation in the Ghanaian banking industry. African Review of Economics and Finance, 6(2), p. 88-114.

ii. Anamuah-Mensah, E. \& Marfo, G., 2009. E-Business Adoption in the Banking Industry in Ghana. Lulea: Lulea University of Technology.

iii. Boateng, R., Molla, A., Heeks, R. \& Hinson, R., 2011. Advancing E-commerce Beyond Readiness in a Developing Economy: Experiences of Ghanaian Firms. Journal of Electronic Commerce in Organizations, 9(1), pp. 1-16.

iv. Turban, E., Lee, J., King, D. \& Chung, H. M., 1999. Electronic Commerce: A Managerial Perspective. New Jersey: Prentice Hall.

v. Zwass, V., 1998. Structure and macro-level impacts of electronic commerce: From technological infrastructure to electronic market places. [Online] Available at: http://www.mhhe.com/business/mis/zwass/ ecpaper.html [Accessed 4 March 2017].

vi. Zwass, V., 1996. Electronic Commerce: Structures and Issues. International Journal of Electronic Commerce, 1(1), pp. 3-23.

vii. Chan, E. \& Swatman, P., 1999. Electronic Commerce: A Component Model. Wellington, s.n.

viii. WTO, 2013. E-commerce in developing countries: Opportunities and challenges for small and medium-sized enterprises, Geneva: Worl Trade Organization.

ix. $\quad$ Gobat, J., 2012. What Is a Bank?. Finance \& Development, 49(1), pp. 38-39.

x. $\quad$ Adams, A. \& Lamptey, A., 2009. Customer perceived value in internet banking in Ghana.. Winneba: University of Education.

xi. $\quad$ Bank of Ghana, 2017. List of licensed banks, representative offices and their registered offices as at December 2016. [Online] Available at: http:// www.bog.gov.gh/ supervision-a-regulation/ register-of-licensed-institutions/ banks [Accessed 4 March 2017].

xii. Asante-Gyabaah, G., Oppong, C. N. \& Idun-Baidoo, N., 2015. Electronic Banking in Ghana: A Case of GCB Bank Ltd. European Journal of Business and Management, 7(12), pp. 239-256.

xiii. Diniz, E. H., Porto de Albuquerque, J. \& Cernev, A. K., 2011. Mobile Money and Payment: A literature review based on academic and practitioner-oriented publications (2001-2011), s.l.: Association For Information Systems.

xiv. Woldie, A., Hinson, R., Iddrisu, H. \& Boateng, R., 2008. Internet banking: an initial look at Ghanaian bank consumer perceptions. Banks and Bank Systems, 3(3), pp. 35-46.

xv. Dada, D., 2006. E-Readiness for developing countries: Moving the focus from the environment to the users. Electronic Journal on Information Systems in Develping Countries, 27(6), pp. 1-14.

xvi. Alaaraj, H. \& Ibrahim, F. W., 2014. An Overview and Classification of E-Readiness Assessment Models. International Journal of Scientific and Research Publications, 4(12), pp. 1-5.

xvii. Franco, C. E. \& Regi, B., 2016. Advantages and challenges of E-commerce customers and businesses: In Indian perspective. International Journal of Research, 4(3), pp. 7-13.

xviii. Kahn, M. A., 2015. E-Readiness in Developing Countries: "A Descriptive Case Study on Banking Sector of Pakistan". Information and Knowledge Management, 5(1), pp. 22-33.

xix. Lin, H.-F., \& Lin, S.-M. (2008). Determinants of e-business diffusion: A test of the technology diffusion perspective. Technovation, 28(3), 135-145.

xx. Morrison, A. J., \& King, B. E. (2002). Small tourism businesses and e-commerce: Victorian tourism online. Tourism and Hospitality Research, 4(2), 104-115.

xxi. Wang, S., \& Cheung, W. (2004). E-business adoption by travel agencies: prime candidates for mobile e-business. International Journal of Electronic Commerce, 8(3), 43-63. 